\title{
Systemic Interleukin-1 Induces Early and Late Patterns of c-fos mRNA Expression in Brain
}

\author{
Linda S. Brady, ${ }^{1}$ Allison B. Lynn, ${ }^{1}$ Miles Herkenham, ${ }^{1}$ and Zehava Gottesfeld ${ }^{2}$ \\ 'Section on Functional Neuroanatomy, Clinical Neuroendocrinology Branch, National Institute of Mental Health, Bethesda, \\ Maryland 20892, and 'Department of Neurobiology and Anatomy, University of Texas, Medical School, Houston, Texas \\ 77225
}

This study was designed to examine the mechanisms by which systemic interleukin-1 affects neuroendocrine systems in the brain. Intraperitoneal injections of interleukin-1 $\beta$ $(1.25 \mu \mathrm{g} / \mathrm{rat})$ were administered to rats. One or three hours after injection, the expression levels of the immediate-early gene $c$-fos and of genes for several neuropeptides, receptors, and enzymes were examined by in situ hybridization histochemistry. In the brainstem at $1 \mathrm{hr}, c$-fos mRNA was elevated in the area postrema and nucleus of the solitary tract, but not in the locus coeruleus. At $3 \mathrm{hr}$, the c-fos mRNA levels had increased further in the nucleus of the solitary tract. Rostrally, elevations in c-fos mRNA levels were found in the hypothalamic and thalamic paraventricular nuclei, central nucleus of amygdala, bed nucleus of the stria terminalis, and medial preoptic area, peaking at $1 \mathrm{hr}$ and diminishing at $3 \mathrm{hr}$. In addition, at $3 \mathrm{hr}$ a new pattern of c-fos activity emerged-the arcuate nucleus and cells at the external margins throughout the brain now expressed $c$-fos mRNA. Corticotropin-releasing hormone mRNA levels were doubled in the paraventricular nucleus at 1 and $3 \mathrm{hr}$, concomitant with elevations in plasma adrenocorticotrophic hormone (ACTH) and corticosterone. Tyrosine hydroxylase mRNA levels in the brainstem did not change.

The c-fos mRNA induction patterns reveal a temporally dynamic response to interleukin-1 administration. We propose that the early set of structures responding to interleukin-1 initiates the neuroendocrine response to $\mathrm{cy}$ tokines. Coactivation of the area postrema and nucleus of the solitary tract may reflect entry into the brain and neural transduction of the peripheral signal. The late set-including the nucleus of the solitary tract, arcuate nucleus, and the brain's edge-may reflect cellular activation along the diffusion routes traveled by interleukin-1 or a bioactive transduction product, because the pattern of edge labeling is similar to the autoradiographic pattern of flow of radiolabeled tracer substances in the cerebrospinal fluid. The late c-fos mRNA response to interleukin-1, therefore, may represent a demonstration of information transfer in the parasynaptic mode, also known as volume transmission.

\footnotetext{
Received Oct. 20, 1993; revised Feb. 3, 1994; accepted Feb. 17, 1994

We thank Pat Foley (UBI) for kindly supplying the IL-1.

Correspondence should be addressed to L. S. Brady, Section on Functional Neuroanatomy, National Institute of Mental Health, Building 36, Room 2D15, Bethesda, MD 20892.

Copyright (C) 1994 Society for Neuroscience $0270-6474 / 94 / 144951-14 \$ 05.00 / 0$
}

[Key words: interleukin-1, c-fos, paraventricular nucleus, hypothalamic-pltuitary-adrenal (HPA) axls, IImblc system, area postrema, nucleus of the solitary tract]

Peripheral administration of the cytokine interleukin-1 (IL- 1) mimics and mediates many of the effects of inflammation and injury, producing fever, sleep, hypophagia, and activation of the endocrine system (Rothwell, 1991). Centrally and peripherally administered IL-1 stimulates the secretion of adrenocorticotrophic hormone (ACTH) from the anterior pituitary gland and glucocorticoids from the adrenal gland (Dunn, 1990). Corticotropin-releasing hormone $(\mathrm{CRH})$, synthesized in median eminence-projecting neurons of the parvocellular division of the paraventricular nucleus (PVN) of the hypothalamus, is the major regulator of activity in the hypothalamic-pituitary-adrenal (HPA) axis. IL-1 stimulates CRH release from the PVN (Berkenbosch et al., 1987; Sapolsky et al., 1987; Uehara et al., 1987; Tsagarakis et al., 1989; Saphier and Ovadia, 1990). The routes by which peripheral IL-1 exerts this effect in brain are not known, and one major obstacle toward their disclosure is the fact that IL-1, a $17 \mathrm{kDa}$ protein, may not cross the blood-brain barrier in significant amounts. The circumventricular organs are obvious candidates for sites of entry of IL- 1 into the brain. Otherwise, the numerous alternative transduction mechanisms that have been proposed have no discrete neuroanatomical locus (Cunningham and De Souza, 1993). However, the anatomy of sources of afferent inputs to the parvocellular PVN is well known (Sawchenko and Swanson, 1983; Whitnall, 1993). Neurochemical evidence suggests a noradrenergic link mediating II - 1 's effects on CRH release (Dunn, 1988; Kabiersch et al., 1988; Chuluyan et al., 1992; MohanKumar and Quadri, 1993), and this would arise from brainstem catecholaminergic neurons located in the A1, A2, or A6 cell groups (Sawchenko and Swanson, 1982). Of these, the A2 cell group, located in the nucleus of the solitary tract (NTS), is a good candidate for mediating IL-1 effects because it is located adjacent to a circumventricular organ, the area postrema (AP), and it supplies the largest noradrenergic input to the parvocellular PVN.

Another route by which IL-1 may activate CRH neurons of the PVN may be through the preoptic area (POA), which has been shown to be part of a forebrain circuit by which peripherally administered IL- 1 affects HPA activity (Katsuura et al., 1990). This hypothesis is attractivc because neurons in the POA participate in temperature regulation (Blatteis, 1989), and the POA lies adjacent to two circumventricular organs, the organum vasculosum of the lamina terminalis (OVLT) and the subforn- 
ical organ (SFO), which could be sites by which IL-1 gains entry into the brain.

A recently developed technique by which responsive neuronal systems can be identified is in situ hybridization of mRNA probes for immediate-early genes such as $c$-fos. The rapid and intense induction of $c$-fos gene expression has proved to be an effective tool in detecting increased intracellular activity, and it is considered to be an early marker of neuronal activation (Sheng and Greenberg, 1990; Morgan and Curran, 1991). Appearance of c-Fos protein is closely linked temporally with $c$-fos gene expression (Sharp et al., 1991). It should be noted, however, that a dissociation of patterns of $c$-fos mRNA activation and 2-dcoxyglucosc utilization, a general marker of metabolic and functional activity, has been noted in some paradigms (Duncan et al., 1993).

We examined the effects of intraperitoneal (i.p.) injections of IL- 1 on activity of candidate brainstem and forebrain cell groups, using in situ hybridization histochemistry of $c$-fos mRNA. In addition, mRNA probes for $\mathrm{CRH}$, tyrosine hydroxylase (TH), thyrotropin-releasing hommone (TRH), thyroid-stimulating hormone (TSH), proopiomelanocortin (POMC), and glucocorticoid receptors were examined in an effort to establish the degree of activation of the HPA axis and to determine whether the synthesis of key transmitters and receptors in the $c$-fos-responsive areas would also be altered by IL-1.

\section{Materials and Methods}

Animals and radioimmunoassays. Male Sprague-Dawley rats (175-200 gm; Taconic Farms, Germantown, NY) were administered intraperitoneal injections of IL- $1 \beta(1.25 \mu \mathrm{g} / \mathrm{rat})$ dissolved in $0.9 \%$ saline or $0.9 \%$ saline alone. The dose is in the low end of the range of doses known to activate the HPA axis (Suda et al., 1990). Animals were killed by decapitation 1 or $3 \mathrm{hr}$ after the treatment. Brains with attached pituitaries were removed, frozen by immersion in 2 -methyl butane at $-30^{\circ} \mathrm{C}$, and stored at $-70^{\circ} \mathrm{C}$ prior to sectioning. Trunk blood was collected on ice in tubes containing ethylenediaminetetraacetic acid and centrifuged, and the plasma was frozen at $-70^{\circ} \mathrm{C}$. ACTH and corticosterone were measured by radioimmunoassay (RIA; ICN Biochemicals Kit, Cleveland, $\mathrm{OH}$ ). The intra-assay and inter-assay coefficients of variance were $<10 \%$.

In situ hybridization histochemistry: Cryostat-cut $15 \mu \mathrm{m}$ thick coronal sections were thaw-mounted onto gelatin-coated slides, dried, and stored at $-40^{\circ} \mathrm{C}$ until processing. Levels collected were POA, supraoptic nucleus (SON), and bed nucleus of the stria terminalis (BNST) at the crossing of the anterior commissure $(-0.4 \mathrm{~mm}$ relative to bregma); midportion of the parvocellular region of the PVN containing also the paraventricular nucleus of the thalamus (PV) and the cingulate cortex $(\mathrm{Cg})(-1.8 \mathrm{~mm})$; central nucleus of the amygdala (ACe) containing also the arcuate nucleus (Arc) and dorsal hippocampus (Hi) $(-3.3 \mathrm{~mm}$ ); pituitary; LC $(-9.7 \mathrm{~mm})$; and medulla at the level of the AP and NTS $(-13.7 \mathrm{~mm})$ (Paxinos and Watson, 1986).

The in situ hybridization protocols were performed as described previously for oligonucleotide (Brady et al., 1990) and ribonucleotide (Whitfield et al., 1990) probes. Synthetic 48-base oligodeoxyribonuclcotide probes, synthesized on a DNA synthesizer ( $\Lambda$ pplied Biosystems, Foster City, CA) and purified on a polyacrylamide gel, were directed against rat CRH bases 496-543 (Jingami et al., 1985), TH bases 14411488 (Grima et al., 1985), TRH bases 319-366 (Lechan et al., 1986), TSH $\beta$ subunit bases encoding amino acids 41-56 (Carr et al., 1987), and POMC bases encoding amino acids 96-111 (Drouin et al., 1985). The probes were labeled at the $3^{\prime}$ end using $\alpha-{ }^{35} \mathrm{~S}-\mathrm{dATP}$ (specific activity $>1000 \mathrm{Ci} / \mathrm{mmol}$; New England Nuclear, Boston, MA), terminal deoxynucleotidyl transferase $(25 \mathrm{U} / \mu \mathrm{l}$; Boehringer-Mannheim Biochemicals, Indianapolis, IN), and tailing buffer (Bethesda Research Laboratories, Bethesda. MD). Ribonucleotide probes were directed against rat $c$-fos bases 1255-2116 (Curran, 1988), glucocorticoid receptor (GR) 1158 bases encoding amino acids 140-525 (Miesfeld et al., 1986), and mineralocorticoid receptor (MR) 513 bases encoding the carboxy-terminal 25 amino acids and a portion of the $3^{\prime}$ untranslated region ( $\Lambda$ rriza et al., 1988). The XGR 14 plasmid containing the GR cDNA was gener- ously provided by Dr. Keith Yamamoto (Department of Biochemistry and Biophysics, University of California, San Francisco) and the plasmid containing the $c$-fos $\mathrm{cDNA}$ was donated by Dr. Tom Curran (Roche Institute of Molecular Biology, Nutley, NJ). Transcription of antisense probes was carried out using the Riboprobe System (Promega Biotech, Madison, WI) in the presence of $\alpha^{-{ }^{35}}$ S-UTP (specific activity $>1000$ $\mathrm{Ci} / \mathrm{mmol}$; New England Nuclear).

Slides and ${ }^{14} \mathrm{C}$ plastic standards containing known amounts of radioactivity (American Radiochemicals, St. Louis, MO) were placed in $\mathrm{x}$-ray cassettes, apposed to film (Hyperfilm- $\beta$ Max, Amersham Corp., Arlington Heights, IL) for varying durations ( $30 \mathrm{~min}$ for POMC; $2-14 \mathrm{~d}$ for $\mathrm{TH}$, receptors, and neuropeptides; and $28 \mathrm{~d}$ for $c$-fos), and developed (D19, Eastman Kodak Co., Rochester, NY) for 5 min at $20^{\circ} \mathrm{C}$. To determine anatomical localization of hybridized probes at the cellular level, sections were dipped in NTB-2 nuclear track emulsion (Eastman Kodak Co.), exposed for 1-3 months, developed (D19, Eastman Kodak Co.) for 2 min at $16^{\circ} \mathrm{C}$, and counterstained with cresyl violet.

Data analysis. Autoradiographic film images of brain sections and standards were digitized on a Macintosh II computer-based image analysis system with IMAGE software (Wayne Rasband, Research Services Branch, National Institute of Mental Health). Light transmittance through the film was measured by outlining the structure on the TV monitor with the mouse cursor. A density-slice function was applied to each structure to select densities greater than film background and thus measure transmittance confined to the cellular sources of the radioactivity. A polynomial calibration curve was constructed using the transmittance values of the standards. Transmittance measurcments for cach probe were made on two to four consecutive sections from each brain region per rat and were converted to $\mathrm{dpm} / \mathrm{mg}$ plastic using the calibration curve.

The average value for each animal in experimental or control groups was used to calculate group means ( $n=4-6$ per group). Statistical significance between brain regions in control and experimental groups was determined by two-way analysis of variance using SUPERANOVA software (Abacus. Berkeley, CA). The Bonferroni/Dunn (all means) test was used for post hoc comparisons of control and experimental group means at 1 and $3 \mathrm{hr}$ time points. A value of $p<0.05$ was chosen as the level of statistical significance.

\section{Results}

Several endocrine measures were employed to gauge the response to the peripheral IL- $1 \beta$ injection. The data indicate that IL- 1 induced a characteristic response in the HPA axis (Table 1). Thus, ACTH and corticosterone levels were elevated in the plasma, with a greater effect at $1 \mathrm{hr}$ than at $3 \mathrm{hr}$. These changes were accompanied by a delayed elevation of POMC MRNA in the anterior pituitary and a selective increase in MR mRNA but not GR mRNA in the hippocampal subfields. The CRH mRNA level was doubled in the PVN at $1 \mathrm{hr}$ and was still elevated at $3 \mathrm{hr}$.

Analysis of the $c$-fos mRNA autoradiographs showed that compared to saline-injected control animals, which showed a characteristic pattern of heterogeneous sparse hybridization of the immediate-early gene, IL-1-injected animals showed dramatic elevations in c-fos mRNA levels in discrete anatomical loci (Figs. 1-7). Differences in pattern as well as amount of probe hybridized were noted between the two time points studied. In the medulla, sites showing marked c-fos mRNA elevations in IL-1-injected relative to control animals were the NTS and AP (Figs. 1, 2; Table 2). Both structures were strongly positive at 1 hr survival, but at $3 \mathrm{hr}$ survival a dissociation occurred such that the NTS had still higher levels of $c$-fos mRNA, whereas the AP had significantly reduced levels compared to $1 \mathrm{hr}$ survival (Table 2 ). In adjacent sections, the TH mRNA signal was localized (Гig. 2d) and measured (Table 1). The strongest labeling was localized not to the NTS but rather to the AP and the dorsal motor nucleus of the vagus. This signal apparently emanates from dopaminergic neurons in these areas (Kalia et 
Table 1. Effects of IL-1 $\beta$ on mRNA expression in brain and pituitary and on plasma hormone secretion

\begin{tabular}{|c|c|c|c|c|}
\hline Measure & $\begin{array}{l}\text { Control, } 1 \mathrm{hr} \\
(N=4)\end{array}$ & $\begin{array}{l}\mathrm{IL}-1 \beta, 1 \mathrm{hr} \\
(N=5)\end{array}$ & $\begin{array}{l}\text { Control, } 3 \mathrm{hr} \\
(N=6)\end{array}$ & $\begin{array}{l}\text { IL- } 1 \beta, 3 \mathrm{hr} \\
(N=5)\end{array}$ \\
\hline \multicolumn{5}{|l|}{ TH } \\
\hline NTS & $96 \pm 15$ & $91 \pm 8$ & $88 \pm 10$ & $97 \pm 12$ \\
\hline LC & & $3,190 \pm 345$ & $2,940 \pm 350$ & $3,010 \pm 247$ \\
\hline \multicolumn{5}{|l|}{$\mathrm{MR}$} \\
\hline $\mathrm{Hi}$ & $606 \pm 32$ & $745 \pm 82^{*}$ & $573 \pm 48$ & $707 \pm 54^{*}$ \\
\hline \multicolumn{5}{|l|}{ GR } \\
\hline $\mathrm{Hi}$ & $500 \pm 67$ & $493 \pm 45$ & $503 \pm 90$ & $499 \pm 85$ \\
\hline \multicolumn{5}{|l|}{ CRII } \\
\hline PVN & $347 \pm 65$ & $703 \pm 157^{* *}$ & $373 \pm 91$ & $690 \pm 146^{* *}$ \\
\hline BNST & $81 \pm 19$ & $82 \pm 7$ & $92 \pm 5$ & $92 \pm 15$ \\
\hline POA & $76 \pm 3$ & $77 \pm 3$ & $76 \pm 2$ & $81 \pm 6$ \\
\hline \multicolumn{5}{|l|}{ POMC } \\
\hline Anterior pituitary & $7,780 \pm 380$ & $8,490 \pm 1,270$ & $7,060 \pm 680$ & $10,290 \pm 1,940^{* *}$ \\
\hline \multicolumn{5}{|l|}{ TRH } \\
\hline PVN & $419 \pm 41$ & $376 \pm 35$ & $377 \pm 20$ & $420 \pm 5$ \\
\hline POA & $257 \pm 22$ & $243 \pm 26$ & $234 \pm 49$ & $235 \pm 21$ \\
\hline \multicolumn{5}{|l|}{ TSH } \\
\hline Anterior pituitary & $412 \pm 72$ & $936 \pm 170^{* *}$ & $447 \pm 120$ & $519 \pm 116 t+$ \\
\hline \multicolumn{5}{|l|}{ Plasma hormones } \\
\hline $\mathrm{ACTH}$ & $82 \pm 17$ & $651 \pm 123^{* *}$ & $37 \pm 10$ & $293 \pm 105 \dagger$ \\
\hline Corticosterone & $96 \pm 24$ & $634 \pm 86^{* *}$ & $91 \pm 39$ & $233 \pm 62+\uparrow$ \\
\hline
\end{tabular}

Data are expressed as mean $\mathrm{dpm} / \mathrm{mg} \pm \mathrm{SD}$ for $\mathrm{mRNA}$ expression, mean $\mathrm{pg} / \mathrm{ml} \pm \mathrm{SEM}$ for $\mathrm{ACTH}$, and mean $\mathrm{ng} / \mathrm{ml} \pm$ SEM for corticosterone.

${ }^{*} P<0.05,{ }^{* *} P<0.01$ relative to the respective $1 \mathrm{hr}$ or $3 \mathrm{hr}$ control group.

$+P<0.05$, $+\dagger P<0.01$ relative to the $1 \mathrm{hr}$ IL- $1 \beta$ group.

al., 1985). Densitometry of the signal confined to the noradrenergic A2 cell group of the NTS region showed that there were no differences between IL-1-treated and control animals at either time point (Tablc 2).

Within the NTS itself, comparison of the location of the $c$-fos mRNA pattern with the TH mRNA pattern indicated that the area covered by $c$-fos mRNA was larger than that covered by TH mRNA. TH mRNA in the NTS was confined to a region ventrolateral to the AP (Fig. $2 d$ ), conforming to the reported location of noradrenergic A2 cells (Kalia et al., 1985). c-fos mRNA at $1 \mathrm{hr}$ was similarly distributed (Fig. 2a), but at $3 \mathrm{hr}$ it was expressed in the A2 sector and also the commissural portion of the NTS, forming a ring of labeling surrounding the $\mathrm{AP}$ and somewhat farther removed from it than had been the case at $1 \mathrm{hr}$ (Fig. 2b).

In the LC, $c$-fos mRNA showed a tendency to be elevated at both 1 and $3 \mathrm{hr}$, but owing to variability of signal in the control animals, and the loss of several sections, the differences were not significant (Table 2). Similarly, TH mRNA was not altered in the LC at either time point (Table 1).

At rostral brain levels, $c$-fos $\mathrm{mRNA}$ expression was induced by IL- 1 in a number of structures, including the PVN (Figs. 36). Nithin the PVN, c-fos mRNA was expressed in both the parvocellular and magnocellular portions (Fig. $5 a$ ), whereas CRH mRNA was confined to the parvocellular portion (Fig. $5 b$ ). Significant elevations in $c$-fos $\mathrm{mRNA}$ levels were found in a number of structures known to project to the PVN, including the POA, BNST, SON, SFO, PV, Arc, and ACe (Figs. 3-6). In all but the Arc, mRNA levels peaked at $1 \mathrm{hr}$ and diminished toward control levels at $3 \mathrm{hr}$ (Table 2). The $c$-fos mRNA elevations at $1 \mathrm{hr}$ were greatest relative to control levels in the SON (9-fold increase), BNST (11-fold increase), ACe (8-fold increase), and PVN (3fold increase). Other areas showed moderate elevations (POA, $\mathrm{PV}$ ) or no changes ( $\mathrm{Hi}$ and $\mathrm{Cg}$ ).

At $3 \mathrm{hr}$, a dramatic new pattern of $c$-fos mRNA activity ap-

\begin{tabular}{|c|c|c|c|c|}
\hline $\begin{array}{l}\text { Brain } \\
\text { region }\end{array}$ & $\begin{array}{l}\text { Control, } \\
1 \mathrm{hr} \\
(N=4)\end{array}$ & $\begin{array}{l}\mathrm{IL}-1 \beta \\
1 \mathrm{hr} \\
(N=5)\end{array}$ & $\begin{array}{l}\text { Control, } \\
3 \mathrm{hr} \\
(N=6)\end{array}$ & $\begin{array}{l}\mathrm{IL}-1 \beta \\
3 \mathrm{hr} \\
(N=5)\end{array}$ \\
\hline NTS & $29 \pm 8$ & $128 \pm 14^{*}$ & $30 \pm 4$ & $240 \pm 12^{*} \dagger$ \\
\hline AP & $40 \pm 5$ & $132 \pm 22^{*}$ & $40 \pm 5$ & $92 \pm 7^{*}+$ \\
\hline $\mathrm{LC}$ & $49 \pm 3$ & $94 \pm 14$ & $87 \pm 45$ & $114 \pm 27$ \\
\hline $\mathrm{Cg}$ & $57 \pm 9$ & $73 \pm 15$ & $56 \pm 15$ & $52 \pm 13$ \\
\hline $\mathrm{Hi}$ & $77 \pm 6$ & $77 \pm 16$ & $69 \pm 5$ & $71 \pm 4$ \\
\hline PV & $101 \pm 6$ & $159 \pm 14^{*}$ & $98+17$ & $128 \pm 23$ \\
\hline Arc & $44 \pm 7$ & $45 \pm 4$ & $40 \pm 3$ & $147 \pm 33^{*}+$ \\
\hline $\mathrm{ACe}$ & $43 \pm 2$ & $353 \pm 58^{*}$ & $34 \pm 5$ & $107 \pm 96 \dagger$ \\
\hline PVN & $61 \pm 10$ & $189 \pm 12^{*}$ & $63 \pm 17$ & $147 \pm 31^{*}$ \\
\hline SON & $19 \pm 6$ & $168 \pm 36^{*}$ & $44 \pm 31$ & $86 \pm 15 \dagger$ \\
\hline BNST & $18 \pm 1$ & $197 \pm 58^{*}$ & $26 \pm 6$ & $80 \pm 14 \dagger$ \\
\hline POA & $43 \pm 7$ & $72 \pm 7^{*}$ & $46 \pm 3$ & $68 \pm 6^{*}$ \\
\hline
\end{tabular}

Data are expressed as mean $\mathrm{dpm} / \mathrm{mg} \pm \mathrm{SD}$.

$* P<0.01$ relative to the respective control group.

$\dagger P<0.01$ relative to the $1 \mathrm{hr}$ IL- $1 \beta$ group. 

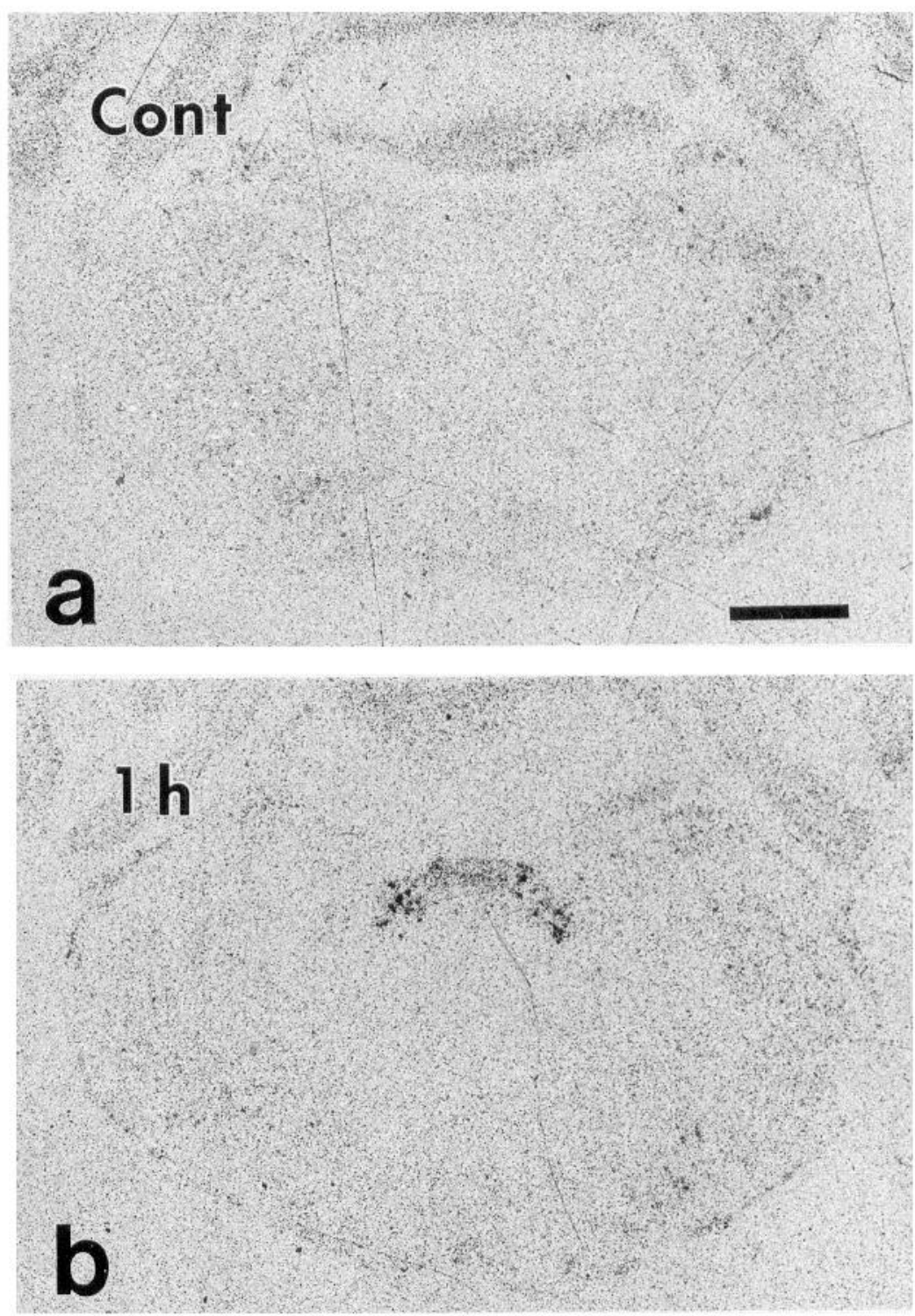

Figure 1. Film autoradiographs of $c$-fos mRNA distribution at the level of the area postrema and nucleus of the solitary tract show the patterns of labeling in the $1 \mathrm{hr}$ control (Cont, $a$ ), 1 $\mathrm{hr}$ post IL-1 injection $(b)$, and $3 \mathrm{hr}$ post IL-1 injection (c). The arrow in $c$ points to labeling of the edge of the brain. Scale bar, $2 \mathrm{~mm}$.

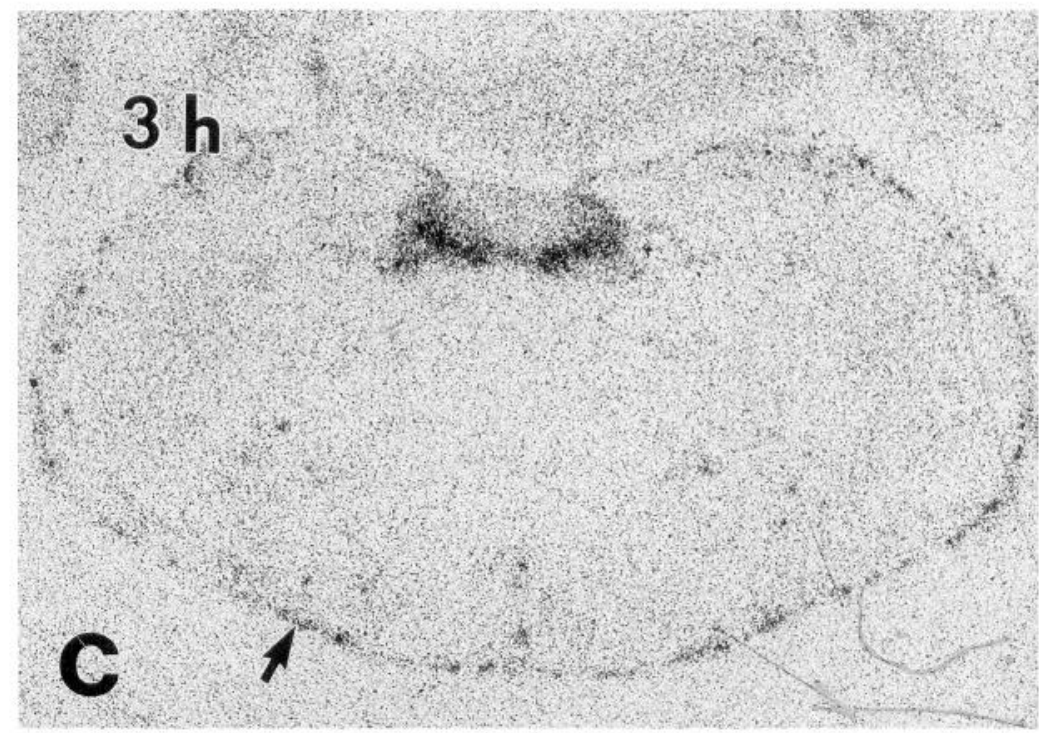



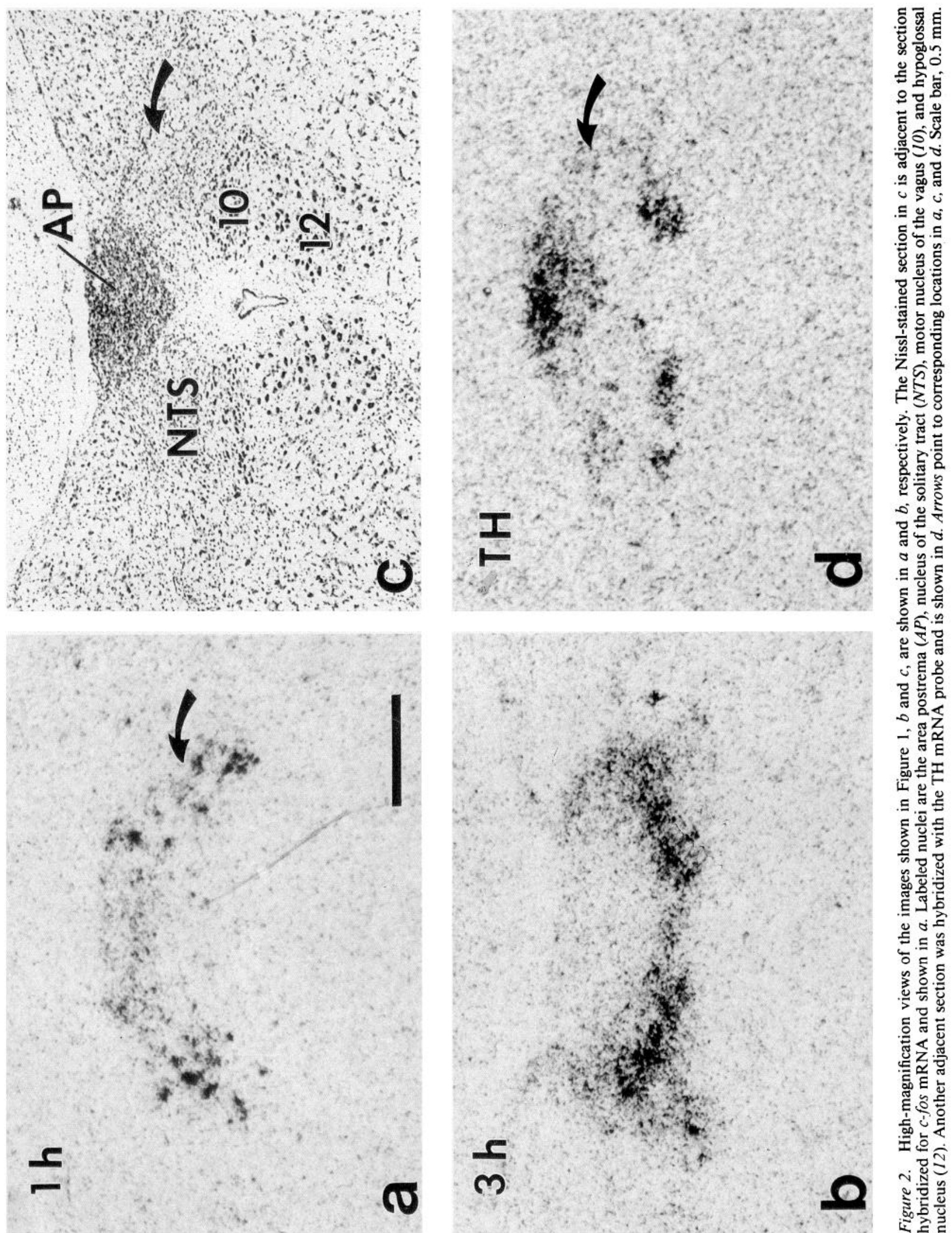


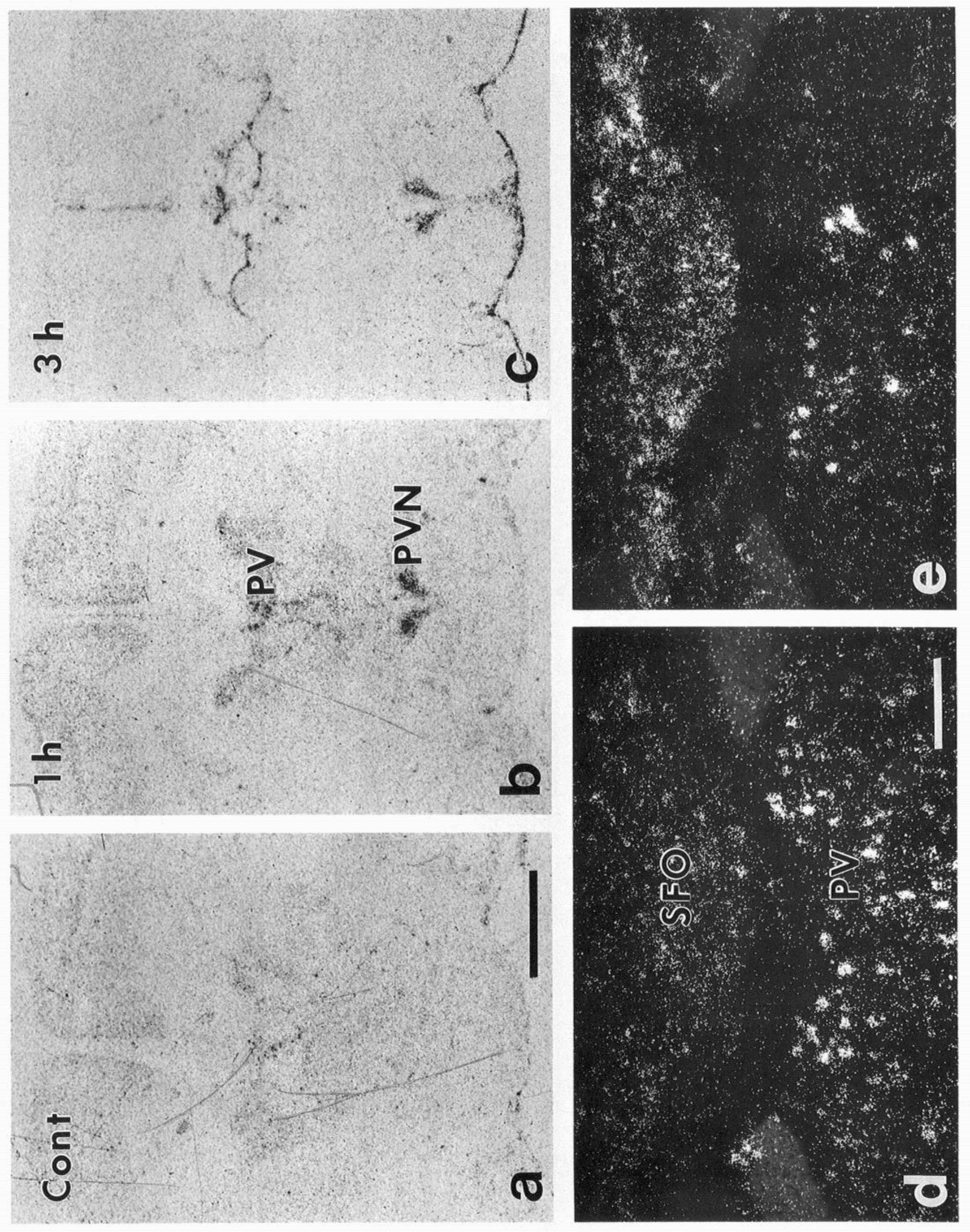


peared along the edges of the brain in the IL-1-treated animals, most prominently on the ventral surface at hypothalamic levels (Figs. $3 c, 4$ ), but extending as far caudally as the medulla (Fig. 1c). By close inspection of IL-1-treated cases at $1 \mathrm{hr}$ survival, however, a predecessor of this "edge" phenomenon was already apparent. Thus, at $1 \mathrm{hr}$, sparse but significant $c$-fos mRNA labeling was observed lying directly over the meninges at the outer margins of the brain at the levels examined (Figs. 4a,c;7a-d). The hybridization signal was typically only severalfold higher than background levels, and it showed a generally consistent pattern of localization over the meninges among the $1 \mathrm{hr}$ IL-1treated brains. High-resolution analysis of emulsion-coated sections showed that both the pia and arachnoid were labeled in locations where the two membranes could be separately identified. This was especially clear in the rhinal sulcus (Fig. $7 \mathrm{C}$ ) and in the region of the circle of Willis, where the subarachnoid space is occupied by major arteries (Fig. 7d).

By $3 \mathrm{hr}$, the labeling intensity at the brain's edges was increased, and the pattern had changed significantly. First, where pia and arachnoid could be identified, only the pia was now labeled (Fig. $7 g, h$ ). Second, additional sites showed the pattern, such as the epithelium of the dorsal surface of the thalamus and the ventral surface of the $\mathrm{Hi}$ and the hippocampal commissure (Figs. 3c, 4e, $7 f$ ). Some sites, however, had similar patterns at both 1 and 3 hr survivals (e.g., $\mathrm{Cg}$ as shown in Fig. $7 a, e$ ). Third, where the edge pattern was strongest, the label was shifted away from the meninges and was instead concentrated over cells lying immediately adjacent to the pia. This localization shift was verified in the emulsion-coated sections (Figs. 4d, 7h), which revealed apparent neuronal expression in the hypothalamus and amygdala. In cortical areas, however, it was not clear what type of cell lying adjacent to the pia in the molecular layer would be c-fos mRNA expressing (Fig. 7g). The SFO was labeled throughout its extent at $3 \mathrm{hr}$ (Fig. 3e), more so than at $1 \mathrm{hr}$ (Fig. $3 d$ ). Finally, the Arc, which was not $c$-fos mRNA positive at $1 \mathrm{hr}$, now expressed high levels of $c$-fos mRNA, and the labeling appeared to be neuronal (Figs. $3 c, 4 e, g$ ).

Ventricular linings also had $c$-fos mRNA label at $3 \mathrm{hr}$ survival, but much sparser and in a discontinuous pattern. Some brains had no label at all in the ventricles, whereas others showed label in discrete patches or strips. Wherever it was found in emulsioncoated sections, the label was associated with ependymal cells in a pattern similar to that of the meningeal labeling (not shown).

Some brains from both IL-1 groups had sparse labeling above background levels in the choroid plexus (e.g., in the lateral ventricle in Fig. 4a,e). The labeling was so sparse and inconsistent that it was not analyzed further. Some control brains had labeling above background levels in the choroid plexus as well (not shown).

\section{Discussion}

\section{Endocrine parameters}

Peripheral administration of IL- $1 \beta$ induced $c$-fos mRNA expression in a number of key brain regions thought to play im- portant roles in the mediation of the neuroendocrine response to peripheral inflammation and injury. Based on the two time points examined in this study, two distinct time-dependent patterns of $c$-fos mRNA activation occurred-early and late. The majority of structures fell into the pattern of early activation; that is, their $c$-fos $\mathrm{mRNA}$ levels were elevated to a greater degree at $1 \mathrm{hr}$ and were diminished at $3 \mathrm{hr}$ postinjection. Most of the endocrine parameters showed changes at $1 \mathrm{hr}$, with some effects persisting at $3 \mathrm{hr}$, consistent with data from other studies. Thus, at $1 \mathrm{hr}$, levels of CRH mRNA in the PVN and ACTH and corticosterone in the plasma were elevated, similar to studies showing HPA activation after peripheral IL- $1 \beta$ administration (Suda et al., 1990; Harbuz et al., 1992). At $3 \mathrm{hr}$, plasma hormone levels dropped, but POMC mRNA levels in the anterior pituitary were elevated. This delayed, apparently compensatory, response has been reported by others (Suda et al., 1990). Hippocampal MR mRNA was elevated throughout the hippocampus at $1 \mathrm{hr}$ (Table 2) and remained elevated at $3 \mathrm{hr}$ only in the CA3-CA4 region (data not shown), whereas hippocampal GR mRNA was unaffected. A similar selective elevation in levels of MR but not GR mRNA was found after acute immobilization stress (Mamalaki et al., 1992). The IL-1-induced elevation in hippocampal MR mRNA expression may be a compensatory transcriptional response to high levels of receptor occupation by elevated circulating corticosterone.

In contrast to the robust activation of the HPA axis, the thyroid axis was relatively unaffected by this dose of IL-1. TRH mRNA levels in the PVN and POA were not changed at either time point, whereas TSH mRNA levels in the anterior pituitary showed a rise at $1 \mathrm{hr}$ and return to control level at $3 \mathrm{hr}$ (Table 1). It is likely that higher doses of IL-1 are required to produce significant changes in this axis.

\section{The early c-fos $m R N A$ pattern}

A great variation in the magnitude of the $c$-fos mRNA elevation was observed in the early group, with some structures (AP, NTS, $\mathrm{ACe}, \mathrm{BNST}$, PVN, SON) showing large increases in $c$-fos mRNA levels and others showing moderate increases (PV, POA) or small increases that were not significant due to an inadequate number of tissue sections per animal or large interanimal variability $(\mathrm{Cg}, \mathrm{LC})$. Structures showing increases also show elevations after exposure to stressors such as immobilization or noxious stimulation (Ceccatelli et al., 1989; Honkaniemi et al., 1992; Pezzone et al., 1992; Senba et al., 1993). Similarities and differences in the $c$-fos mRNA levels and distribution patterns resulting from cytokines versus stressors deserve further careful analysis. An obvious difference deserving mention is the dramatic and selective elevation in c-fos mRNA expression in the NTS and AP, a phenomenon not observed after stress.

The ascending noradrenergic projections to the PVN appear to be an important component of the HPA response to periphcral IL-1 administration becausc 6-OHDA lesions that deplete norepinephrine in the PVN also attenuate the HPA response (plasma corticosterone elevation) to intraperitoneal IL-1 ad-

\section{$\leftarrow$}

Figure 3. Film autoradiographs of $c$-fos mRNA distribution at the level of the hypothalamic paraventricular nucleus ( $P V N)$ show the patterns of labeling in the $1 \mathrm{hr}$ control $(C o n t, a), 1 \mathrm{hr}$ post IL-1 injection $(b)$, and $3 \mathrm{hr}$ post IL-1 injection $(c)$. Photomicrographs of the thalamic paraventricular nucleus $(P V)$ and subfornical organ $(S F O)$ are shown by dark-field illumination of emulsion-coated sections from $1 \mathrm{hr}(d)$ and $3 \mathrm{hr}(e)$ survival cases. Labeled cells appear as chisters of white dots (silver grains in the emulsion). Scale bars: $a, 2 \mathrm{~mm} ; d, 0.2 \mathrm{~mm}$. 

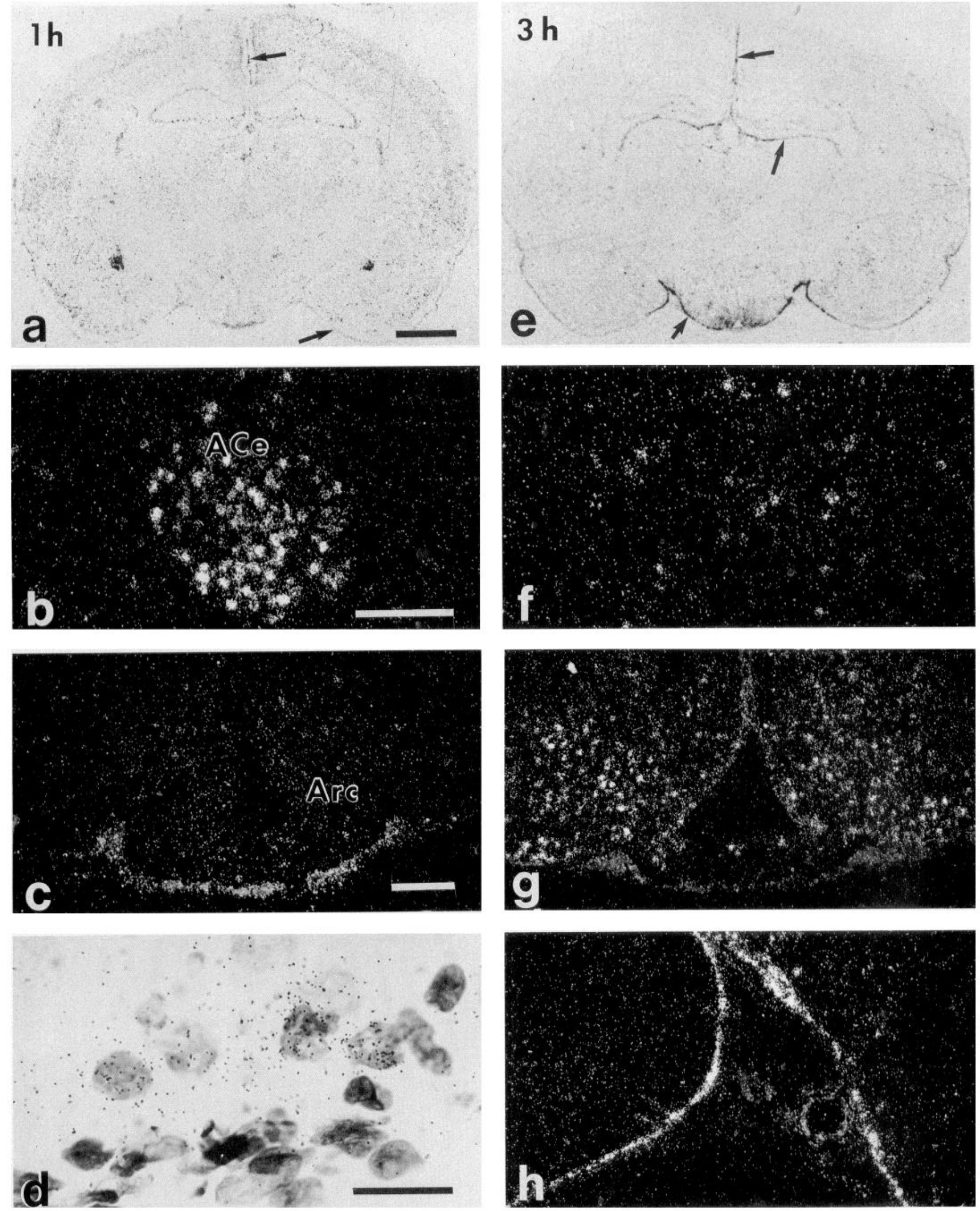

Figure 4. Film and emulsion autoradiographs of $c$-fos mRNA distribution at the level of the central amygdaloid nucleus (ACe) show the patterns of labeling in the $1 \mathrm{hr}(a-c)$ and $3 \mathrm{hr}(d-h) \mathrm{IL}-1$-injected groups. Arrows in $a$ point to edge labeling of non-neuronal cells lining the outer edges of the brain. Arrows in $e$ point to edge labeling which is both neuronal and non-neuronal, depending on location. See text for further details. Scale bars: $a, 2 \mathrm{~mm} ; b$ and $c, 0.2 \mathrm{~mm} ; d, 20 \mu \mathrm{m}$. 

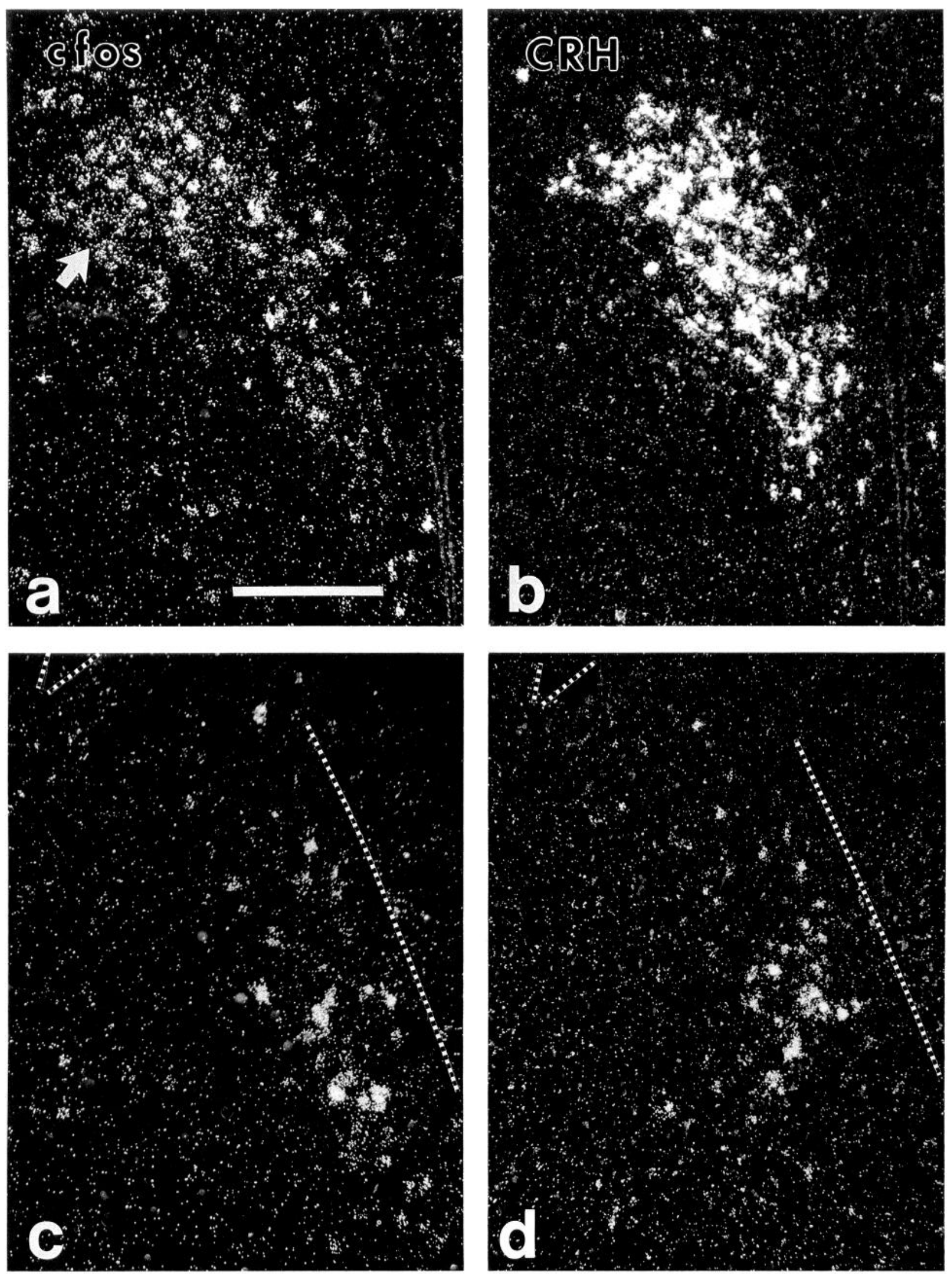

Figure 5. Dark-field photomicrographs of emulsion-coated sections hybridized for $c$-fos mRNA $(a, c)$ or CRH mRNA $(b, d)$ in the paraventricular nucleus ( $a$ and $b$; midline is to the right) or bed nucleus of the stria terminalis ( $c$ and $d$; midline is to the left).Dashed lines mark the locations of the bottom of the lateral ventricle and the medial edge of the internal capsule. Scale bar, $0.2 \mathrm{~mm}$. 


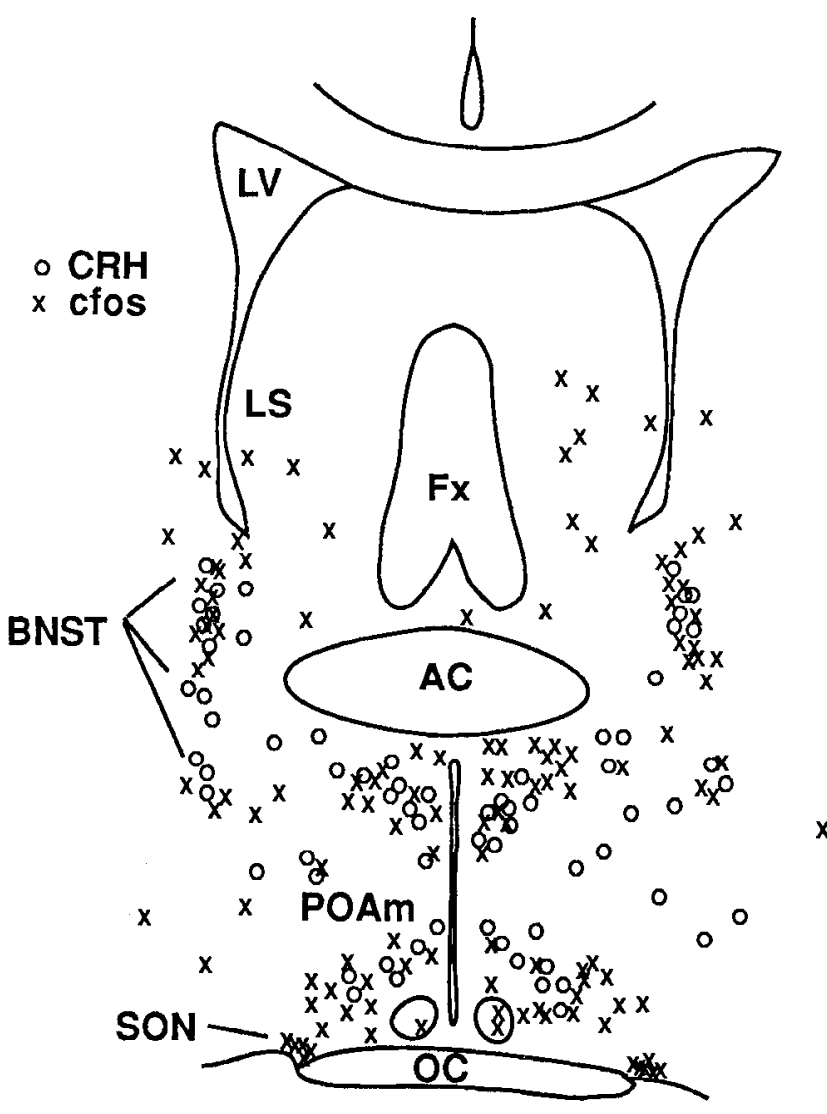

Figure 6. Projection drawing of a section at the level of the anterior commissure $(A C)$, bed nucleus of the stria terminalis $(B N S T)$, fornix $(F x)$, lateral septum $(L S)$, optic chiasm $(O C)$, medial preoptic area $(P O A m)$, and supraoptic nucleus $(S O N)$. Cells expressing mRNAs for c-fos or CRH $1 \mathrm{hr}$ following IL-1 injection were plotted from adjacent sections with a camera lucida attachment to the microscope.

ministration (Chuluyan et al., 1992). This is consistent with the demonstration that brainstem noradrenergic efferents to the PVN regulate the secretion of CRH (Al-Damluji, 1988; Szafarczyk et al., 1988; Plotsky et al., 1989; Saphier and Feldman, 1989). The sources of noradrenergic projections to the parvocellular PVN include noradrenergic cells in the NTS (A2 cell group) and, to a lesser extent, the LC (A6 cell group) (Sawchenko and Swanson, 1982). The present $c$-fos mRNA results suggest that the NTS and not the LC may be the source of the noradrenergic effect on HPA function. One other study has reported the induction of c-Fos immunoreactivity in A2 and also the A1 cell group of the ventrolateral medulla following intraperitoneal endotoxin (lipopolysaccharide) administration (Wan et al., 1993).

Our results do not address the issue of whether the cells expressing $c$-fos mRNA in the NTS arc noradrencrgic. The activation of catecholaminergic cells is consistent with previous studies showing that the systemic administration of IL-l elicits an increase in norepinephrine metabolism in the brain, predominantly in the PVN (Dunn, 1988; Kabiersch et al., 1988). However, it is also true that TH mRNA levels were not altered at the time points examined (Table 1). Perhaps release of small amounts of norepinephrine from terminals in the hypothalamus (Kabiersch et al., 1988) may not induce compensatory transcription of TH mRNA.

Within the NTS region, the area showing $c$-fos mRNA ele- vation is larger than the A2 cell group defined by TH mRNA, though the two patterns overlap. Thus it appears that not all c-fos-positive neurons are noradrenergic. Nevertheless, based on the present data, the A2 cell group in the NTS logether with associated neurons in the NTS and AP may represent the medullary link to the $\mathrm{CRH}$-containing neurons mediating the HPA response to IL-1. This suggestion is made more intriguing by the fact that the AP, a circumventricular organ, may be a site by which peripheral IL-1 can enter the brain to exert its effects. This possibility deserves further study. The AP is not enriched in IL-1 receptors, but neither are any of the other brain sites that have been shown to be responsive to locally applied IL-1 (Tsagarakis et al., 1989; Wilkinson et al., 1993).

Within the PVN, $c$-fos mRNA levels were increased at 1 and $3 \mathrm{hr}$ (Table 2). Similarly, c-Fos immunostaining in the PVN was increased at $0.5-3 \mathrm{hr}$ after peripheral lipopolysaccharide administration (Wan et al., 1993). However, another study utilizing immunostaining of $\mathrm{c}$-Fos protein failed to demonstrate an increase in the PVN at either $30 \mathrm{~min}$ or $2 \mathrm{hr}$ after intravenous administration of $1 \mu \mathrm{g}$ of IL- $1 \beta$ (Rivest et al., 1992). It is difficult to explain this discrepancy with the present data except to suggest that the immunocytochemistry procedure is not as sensitive as the in situ hybridization riboprobe procedure. Alternatively, the discrepancy may be due to different mechanisms activated by the two systemic routes of IL-1 administration or the slightly different doses used. The failure to find a $\mathrm{c}$-Fos protein change in the Arc at $30 \mathrm{~min}$ and $2 \mathrm{hr}$ after peripheral IL-1 injection (Rivest et al., 1992) is probably due to the fact that the Arc $c$-fos mRNA response is so delayed.

Histochemical dọuble-labeling studies have shown that many of the parvocellular PVN neurons that show c-Fos protein elevations in response to central IL- 1 administration are also CRH positive (Ju et al., 1991; Rivest et al., 1992). The location of induced $c$-fos mRNA expression in the magnocellular portion of the PVN as well as the SON indicates involvement of another transmitter phenotype, perhaps oxytocin (Chang et al., 1993), with unknown functional significance. Similar elevations in the magnocellular neurons result from immobilization stress (Pezzone et al., 1992).

IL-1 also stimulated $c$-fos mRNA expression in the POA, BNST, and ACe (Figs. 4-6, Table 2). The BNST is a major source of inputs to the PVN (Sawchenko and Swanson, 1983), and it relays ACe projections to the PVN (Gray et al., 1989). Both the BNST and the ACe are involved in control of HPA activity (Dunn and Whitener, 1986; Dunn, 1987; Feldman et al., 1990).

The ACe also shows selective c-Fos activation following acute administration of imipramine (Duncan et al., 1993), a drug that elevates catecholamine levels in terminal regions by blocking monoamine uptake. The $\mathrm{ACe}$ is a recipient of catecholaminergic input from brainstem cell groups including the NTS (Fallon et al., 1978; Riche et al., 1990; Zardetto-Smith and Gray, 1990). Thus, the ACe stands in a position to be a crucial relay for ascending influences on HPA activity. However, $c$-fos mRNA levels drop significantly at $3 \mathrm{hr}$ compared to $1 \mathrm{hr}$, whereas levels in the NTS increase over the same time course (Table 2). Therefore, it may be the case that the ACe is under other influences, possibly negative glucocorticoid feedback.

In addition to the parvocellular PVN and BNST, the POA (Fig. 6) and ACe (Wray and Hoffman, 1983) contain both $c-f o s$ mRNA expression and CRH in similar locations and patterns. It is not possible to say whether the $c$-fos mRNA-positive cells 
were also CRH mRNA positive. Even if they are not colocalized, however, the overlap allows the possibility that $\mathrm{CRH}$ resides in a population of neurons that has a local domain of influence that includes the neighboring $c$-fos mRNA-cxpressing neurons. The nature of this realm of influence, as well as the factors that determine the selection of active neurons, await further study.

\section{The late c-fos $m R N A$ pattern}

In contrast to the early pattern that is produced also by stressful manipulations, the second pattern of $c$-fos mRNA activationthe late pattern - bears no resemblance to any pattern hitherto reported. Participating in the late response pattern are structures that are elevated at $1 \mathrm{hr}$ and still more so at $3 \mathrm{hr}$ (NTS and SFO), and those that show no $c$-fos mRNA activity until $3 \mathrm{hr}$ (Arc and "edge" neurons). The NTS might be the structure that maintains elevated activity in its target regions, which include both the SFO and the PVN (Shioya and Tanaka, 1989), though it apparently does so without continued "driving" from elevated activity in the AP or forebrain nuclei that project to it (PVN, BNST, and ACe have diminished but still elevated $c$-fos mRNA levels at $3 \mathrm{hr}$ ). In contrast to such speculations based on connectional data, however, it is apparent that the functional origin of the "edge" response pattern cannot be mediated by axonal pathways and requires instead a humoral mechanism to transmit widespread influences on neuronal activity.

In this regard, it is important to note that the late $c$-fos mRNA pattern does not appear to represent IL-1 receptor-mediated transport or transduction across the blood-brain barrier at blood vessels, sites that might have been candidates because of the presence of IL- 1 receptor $m$ RNA expression in endothelial cells (Cunningham et al., 1992; Cunningham and De Souza, 1993), or at the choroid plexus, which is IL-1 receptor rich (Ban et al., 1991). Blood vessels and choroid plexus were not sites of $c$-fos mRNA activation at either time point in this study.

An alternative route of entry of IL- 1 into the brain is carriermediated transport across the blood-brain barrier (Banks et al., 1991). If the saturable and specific transporters for IL-1 have a discrete anatomical distribution, then the $3 \mathrm{hr} c$-fos mRNA pattern might reflect the brain's response to such a route of entry. This is an attractive hypothesis in some regards, but anatomical mapping studies of transporter site distributions are needed to validate it further. Also, it is not evident what physiological correlate would attend this phenomenon if the late $c$-fos $m R N A$ response is indeed reflecting a successful transport across the blood-brain barricr in these locations. The timing would suggest that it is not responsible for the endocrine changes that occur earlier.

Based on its distribution, a likely explanation for the late $c$-fos mRNA pattern is that it represents activation of neurons lying in the path of bulk fluid flow of cerebrospinal fluid (CSF) through the ventricles, subarachnoid spaces, and interstitial spaces. The striking similarity of the $c$-fos mRNA pattern with the pattern of ${ }^{14} \mathrm{C}$-inulin distribution following ventricular injection (Hutto et al., 1987) supports this possibility. In that study, ${ }^{14} \mathrm{C}$-inulin, which is a useful marker of CSF flow because it is not taken up by cells or inactivated, was injected into the cisterna magna, and at varying survival times ranging from $5 \mathrm{~min}$ to $2 \mathrm{hr}$, animals were killed and processed for autoradiographic localization of the distributed tracer. The pattern at 5 min was one of label traveling in the subarachnoid spaces, clearly marking the brain's edge along its entire rostral-caudal extent. Most of the label was concentrated on the ventral surfaces at rostral levels, though it was dense also at the thalamic-hippocampal interfaces and in the cingulate gyrus (Hutto et al., 1987; M. Herkenham, L. Brady, and B. Hutto, unpublished observations). At longer survival times, label penetrated the brain parenchyma, notably in the ventral hypothalamus. When ${ }^{125} \mathrm{I}-\mathrm{CRH}$ was administered in a similar fashion, only the edge sites became labeled, even at long survival times. The deepest penetration occurred in the ventral hypothalamus. The absence of deeper penetration was probably due to degradation of the peptide by proteases. Similarly, inactivation of IL- 1 or its bioactive transduction products such as other cytokines or eicosanoids (Rothwell, 1991) might occur. Interestingly, the median eminence, another circumventricular organ, was largely devoid of both ${ }^{14} \mathrm{C}$-inulin (Hutto et al., 1987) and $c$-fos mRNA expression (Fig. $4 g$ ). This may be due to the rapid clearance of molecules from this site by blood.

If $\mathrm{IL}-1$ is the molecule inducing $c$-fos mRNA expression in these edge cells, then we suggest that it entered the CSF via one or more of the circumventricular organs, all of which protrude into ventricular cavities (hence their name). The delay in $c$-fos mRNA activation is somewhat harder to explain because the ${ }^{14} \mathrm{C}$-inulin data (Hutto et al., 1987) indicate that the subarachnoid spaces of the entire brain, including the ventral hypothalamus, are perfused within 5 min of administration of the tracer into the cisterna magna. The delay suggests that there are intervening events, possibly synthesis of endogenous cytokines or other bioactive substances that then gain access to the ventricular and subarachnoid CSF. In support of this notion is the fact that meninges in discrete regions appeared to be lightly $c$-fos mRNA expressing at $1 \mathrm{hr}$ survival (Figs. 4a,c;7a-d), followed by greater labeling of pia and adjacent cells at $3 \mathrm{hr}$ survival (Figs. $4 e, h ; 7 e-h$ ). Perhaps these non-neuronal cells and cells residing adjacent to them are participating in the process of further production of IL-1 in similarly localized macrophages and microglia at the later survival times, as suggested by data showing induction of IL-1 synthesis in these cells several hours after peripheral endotoxin administration (van Dam et al., 1992).

The failure of IL-1 applied intracerebroventricularly to induce c-Fos protein immunoreactivity in the edge regions at $3 \mathrm{hr}$ survival is somewhat surprising (Chang et al., 1993). However, differences in methodology may account for the negative result. Alternatively, the active molecule(s) may not be IL-1.

We cannot say whether the $3 \mathrm{hr}$-fos mRNA activation pattern reflects a clearance phenomenon or events that have other physiological significance. Further speculation would require better knowledge of the physiological and neurochemical events that occur several hours following a sudden increase in plasma IL- 1 levels. One study showed a delayed response of serotonergic markers, whose levels peaked $8 \mathrm{hr}$ after intraperitoneal endotoxin administration (Dunn, 1992). It is interesting to note that the Arc is activated exclusively as part of the late response. The Arc contains numerous varieties of neuropeptides, and it is the sole source of $\beta$-cndorphin (Finley et al., 1981) and growthhormone-releasing factor (Sawchenko et al., 1985) in the brain. Future work could address the possible functional correlates of late activation of these and other peptidergic systems.

\section{Conclusions}

The present data show that IL-1 administered peripherally induces $c$-fos gene expression in key structures thought to elevate $\mathrm{CRH}$ activity in the parvocellular PVN, resulting in activation of the neuroendocrine axis. These key structures include the $\mathrm{BNST}$ and $\mathrm{ACe}$, which are relays of limbic influences mediating 

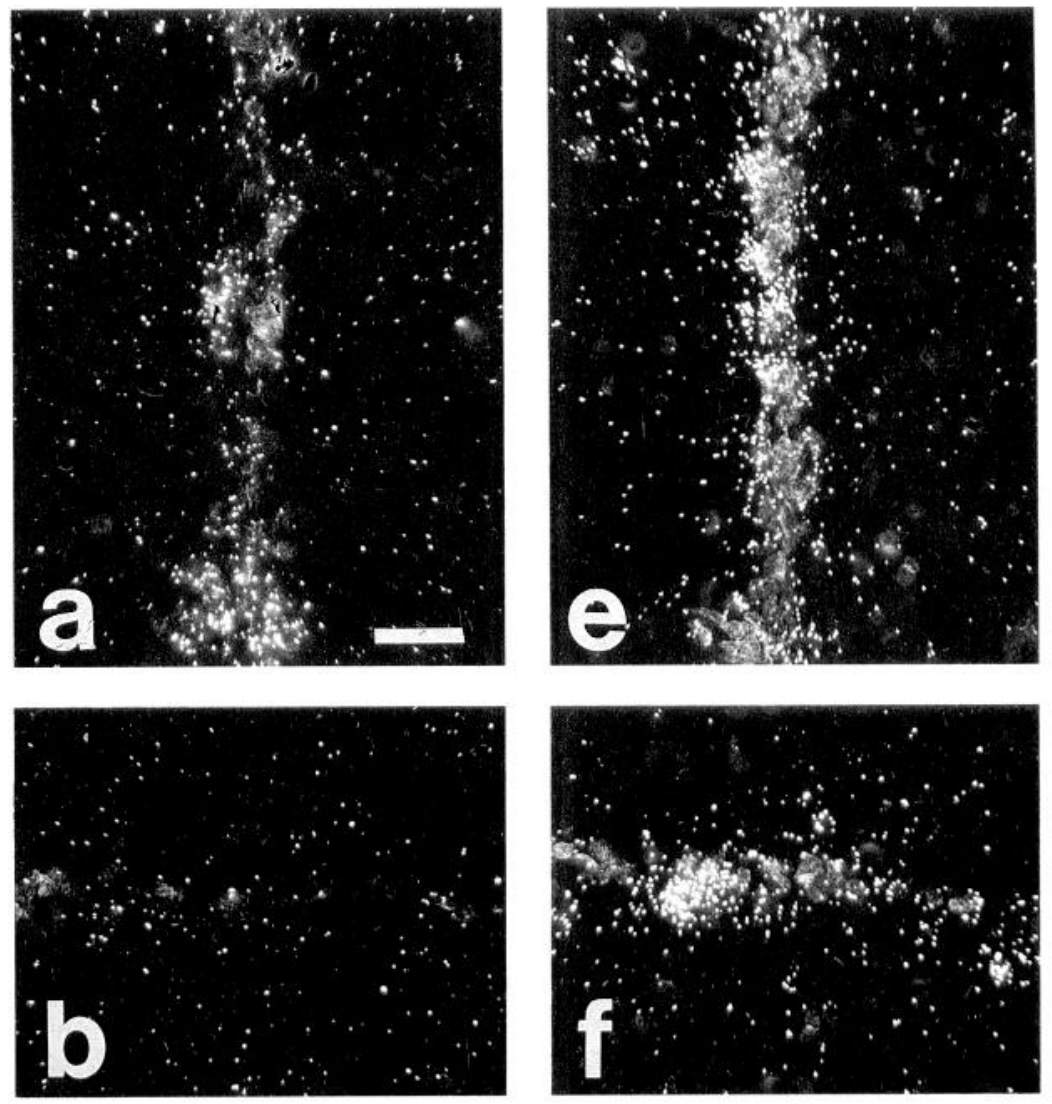

Figure 7. Dark-field photomicrographs of emulsion-coated sections hybridized for $c$-fos mRNA in the $1 \mathrm{hr}(a-$ $d)$ and $3 \mathrm{hr}(e-h)$ IL-1-injected groups. $a$ and $e$ show the pia separating the cingulate cortices; $b$ and $f$ show pia separating thalamus from hippocampus; $c$ and $g$ show the rhinal sulcus on the right side, with the pia and arachnoid (arrow) labeled in $c$, but only the pia labeled in $g$, and $d$ and $h$ show an artery in the subarachnoid space at the base of the hypothalamus, with the arrows pointing to the arachnoid, which is sparsely labeled at $1 \mathrm{hr}$. At $3 \mathrm{hr}$, neurons inside the pia are labeled in $h$. Scale bars: $a$, $100 \mu \mathrm{m}$ for $a, b, e$, and $f ; c, 100 \mu \mathrm{m}$ for $c, d, g$, and $h$.
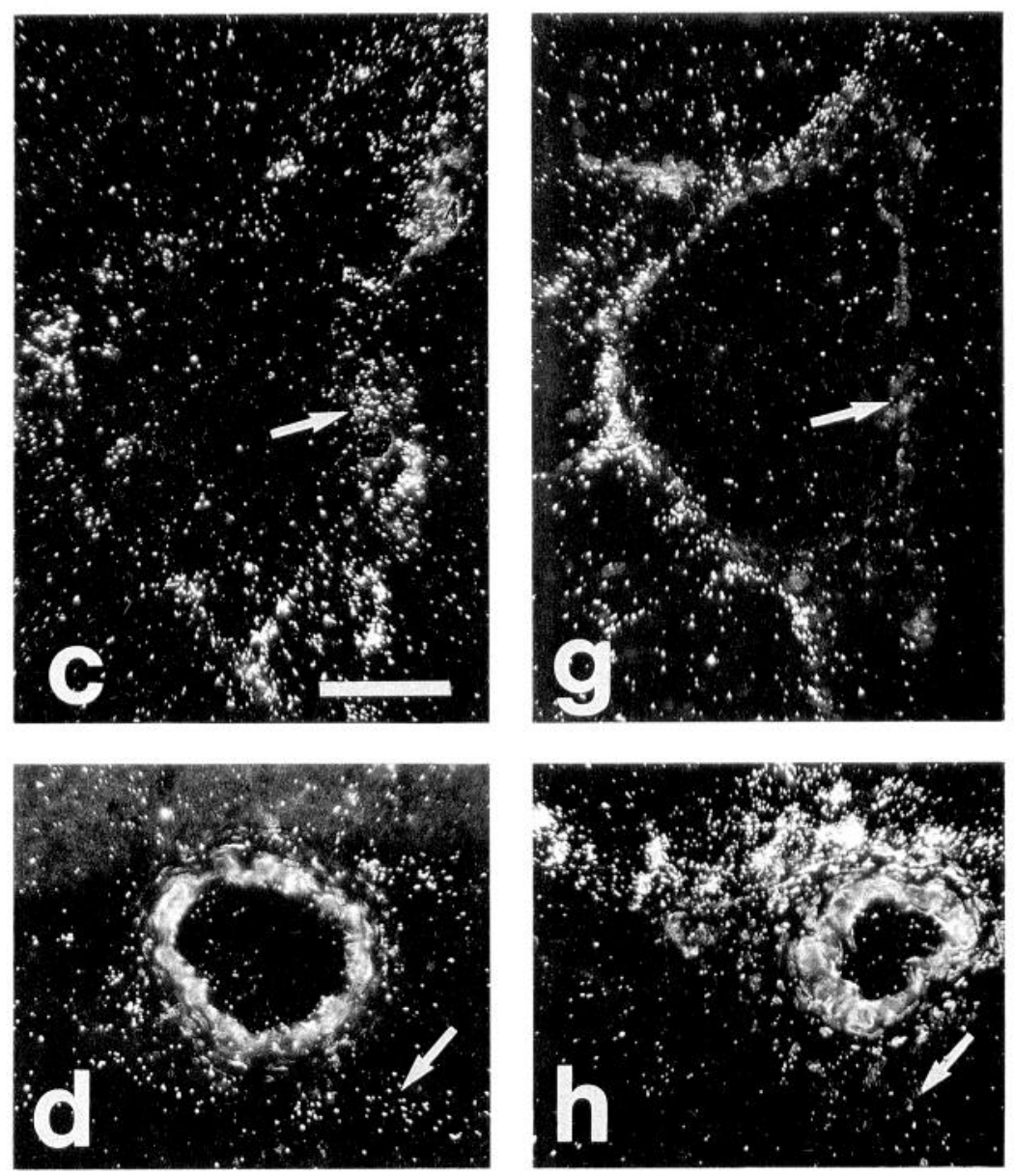
emotionally charged stimuli. In addition, the NTS, by its dramatic and sustained activation, may be the origin of noradrenergic control of HPA responses to inflammatory mediators. If so, the induction of $c$-fos $\mathrm{mRNA}$ expression in the adjacent AP may locate the transduction site by which IL-1 penetrates the blood-brain barrier to exert its cffects centrally. The POA, another candidate for mediation of peripheral IL-1 effects on the HPA axis, showed only small $c$-fos mRNA elevations over control levels at both 1 and $3 \mathrm{hr}$ survivals. The small effect in the POA after peripheral IL-1 injections can be contrasted with the robust c-Fos antigen response in the OVLT and POA following intracerebroventricular angiotensin administration (Herbert et al., 1992), suggesting site-specific actions at circumventricular organs.

A late $c$-fos mRNA response to IL- 1 involves cells lining the external surfaces of the brain. The pattern suggests flow of bioactive substances in the CSF. It is suggested that this may reflect information transfer between the immune system and the brain involving neuronal activation in the Arc and/or non-neuronal induction of cytokine synthesis in the brain. We propose that the late $c$-fos mRNA response to IL-1 represents a demonstration of intcrccllular communication in the parasynaptic mode (Schmitt, 1984), also known as volume transmission (Fuxe and Agnati, 1991).

\section{References}

Al-Damluji S (1988) Adrenergic mechanisms in the control of corticotropin secretion. J Endocrinol 119:5-14.

Arriza JL, Simerly RB, Swanson I.W, Fvans RM (1988) The neuronal mineralocorticoid receptor as a mediator of glucocorticoid response. Neuron 1:887-900.

Ban E, Milon G, Prudhomme N, Fillion G, Haour F (1991) Receptors for interleukin-1 $(\alpha$ and $\beta$ ) in mouse brain: mapping and neuronal localization in hippocampus. Neuroscience 43:21-30.

Banks WA, Ortiz L, Plotkin SR, Kastin AJ (1991) Human interleukin (IL) $1 \alpha$, murine IL- $1 \alpha$ and murine IL- $1 \beta$ are transported from blood to brain in the mouse by a shared saturable mechanism. J Pharmacol Exp Ther 259:988-996.

Berkenbosch F, Oers JV, Rey AD, Tilders F, Besedovsky H (1987) Corticotropin-releasing factor producing neurons in the rat activated by interleukin-1. Science 238:524-526.

Blatteis C (1989) The neurobiology of endogenous pyrogens. In: Thermoreception and temperature regulation (Bligh J, Voigt K, eds), pp 257-272. Berlin: Springer.

Brady LS, Smith MA, Gold PW, Herkenham M (1990) Altered expression of hypothalamic neuropeptide mRNAs in food-restricted and food-deprived rats. Neuroendocrinology 52:441-447.

Carr FE, Need LR, Chin WW (1987) Isolation and characterization of the rat thyrotropin $\beta$-subunit gene. Differential regulation of the two transcriptional start sites by thyroid hormone. J Biol Chem 262 : 981-987.

Ceccatelli S, Villar MJ, Goldstein M, Hökfelt ' $T$ ( (1989) Expression of c-Fos immunoreactivity in transmitter-characterized neurons after stress. Proc Natl Acad Sci USA 86:9569-9573.

Chang SL, Ren T, Zadina JE (1993) Interleukin-1 activation of FOS proto-oncogene protein in the rat hypothalamus. Brain Res 617:123130.

Chuluyan EH, Saphier D, Rohn WM, Dunn AJ (1992) Noradrenergic innervation of the hypothalamus participates in adrenocortical responses to interleukin-1. Neuroendocrinology 56:106 111.

Cunningham ET Jr, De Souza EB (1993) Interleukin 1 receptors in the brain and endocrine tissues. Immunol Today 14:171-176.

Cunningham ET Jr, Wada E, Carter DB, Tracey DE, Battey JF, De Souza EB (1992) In situ histochemical localization of type I interleukin-1 receptor messenger RNA in the central nervous system, pituitary, and adrenal gland of the mouse. J Neurosci 12:1101-1114.

Curran T (1988) The fos oncogene. In: The oncogene handbook (Reddy EP, Skalka AM, Curran T, eds), pp 307-325. Amsterdam: Elsevier.

Drouin J, Chamberland M, Charron J, Jeannotte L, Nemer M (1985)
Structure of the rat pro-opiomelanocortin (POMC) gene. Fed Eur Biochem Soc Lett 193:54-58.

Duncan GE, Johnson KB, Breese GR (1993) Topographic patterns of brain activity in response to swim stress: assessment by 2-deoxyglucose uptake and expression of Fos-like immunoreactivity. J Neurosci 13: 3932-3943.

Dunn AJ (1988) Systemic interleukin-1 administration stimulates hypothalamic norepinephrine metabolism paralleling the increased plasma corticosterone. Life Sci 43:429-435.

Dunn AJ (1990) Interleukin-1 as a stimulator of hormone secretion. Prog Neuroendocrinimmunol 3:26-34.

Dunn AJ (1992) Endotoxin-induced activation of cerebral catecholamine and serotonin mctabolism: comparison with intcrlcukin-1. J Pharmacol Exp Ther 261:964-969.

Dunn JD (1987) Plasma corticosterone response to electrical stimulation of bed nucleus of the stria terminalis. Brain Res 407:327-331.

Dunn JD, Whitener J (1986) Plasma corticosterone response to electrical stimulation of the amygdaloid complex: cytoarchitectural specificity. Neuroendocrinology 42:211-217.

Fallon JH, Koziell DA, Moore RY (1978) Catecholamine innervation of the basal forebrain. II. Amygdala, suprarhinal cortex and entorhinal cortex. J Comp Neurol 180:509-532.

Feldman S, Conforti N, Saphier D (1990) The preoptic area and bed nucleus of the stria terminalis are involved in the effects of the amygdala on adrenocortical secretion. Neuroscience 37:775-779.

Finley JCW, Lindström P, Petrusz P (1981) Immunocytochemical localization of $\beta$-endorphin-containing neurons in the rat brain. Neuroendocrinology 33:28-42.

Fuxe K, Agnati LF (1991) Volume transmission in the brain: novel mechanisms for neural transmission. New York: Raven.

Gray TS, Carney ME, Magnuson DJ (1989) Direct projections from the central amygdaloid nucleus to the hypothalamic paraventricular nucleus: possible role in stress-induced adrenocorticotropin release. Neuroendocrinology 50:433-446.

Grima B, Lamouroux A, Blanot F, Biquet NF, Mallet J (1985) Complete coding sequence of rat tyrosine hydroxylase mRNA. Proc Natl Acad Sci USA 82:617-621.

Harbuz MS, Stephanou A, Sarlis N, Lightman SL (1992) The effects of recombinant human interleukin (IL)- $1 \alpha$, IL- $1 \beta$ or IL- 6 on hypothalamo-pituitary-adrenal axis function. J Endocrinol 133:349-355.

Herbert J, Forsling ML, Howes SR, Stacey PM, Shiers HM (1992) Regional expression of $c$-fos antigen in the basal forebrain following intraventricular infusions of angiotensin and its modulation by drinking either water or saline. Neuroscience 51:867-882.

Honkaniemi J, Kainu T, Ceccatelli S, Rechardt L, Hökfelt T, PeltoHuikko $M$ (1992) Fos and jun in rat central amygdaloid nucleus and paraventricular nucleus after stress. Neuroreport 3:849-852.

Hutto B, Brady L, Herkenham M (1987) Autoradiographic localization of flow of tracer substance in extracellular fluid compartments of rat CNS. Soc Neurosci Abstr 13:485.

Jingami H, Mizuno N, Takahashi H, Shibahara S, Furutani Y, Imura H, Numa S (1985) Cloning and sequence analysis of cDNA for rat corticotropin-releasing factor precursor. Fed Eur Biochem Soc Lett 191:63-66.

Ju G, Zhang X, Jin B-Q, Huang C-S (1991) Activation of corticotropinreleasing factor-containing neurons in the paraventricular nucleus of the hypothalamus by interleukin-1 in the rat. Neurosci Lett 132:151154.

Kabiersch A, Del Rey A, Honegger CG, Besedovsky HO (1988) Interleukin-1 induces changes in norepinephrine metabolism in the rat brain. Brain Behav Immunol 2:267-274.

Kalia M, Fuxe K, Goldstein M (1985) Rat medulla oblongata. II. Dopaminergic, noradrenergic ( $\mathrm{A} 1$ and $\mathrm{A} 2$ ) and adrenergic neurons, nerve fibers, and presumptive terminal processes. J Comp Neurol 233:308-332.

Katsuura G, Arimura A, Koves K, Gottschall PE (1990) Involvement of organum vasculosum of lamina terminalis and preoptic area in interleukin 1 $\beta$-induced ACTH release. Am J Physiol 258:E163-E1 71.

Lechan RM, Wu P, Jackson IMD, Wolfe HC, Cooperman S, Mandel G, Goodman RH (1986) Thyrotropin-releasing hormone precursor: characterization in rat brain. Science 231:159-161.

Mamalaki E, Kvetnansky R, Brady LS, Gold PW, Herkenham M (1992) Repeated immobilization stress alters tyrosine hydroxylase, corticotropin-releasing hormone, and corticosteroid receptor mRNA levels in rat brain. J Neuroendocrinol 4:689-699. 
Miesfeld R, Rusconi S, Godowski PJ, Maler BA, Okret S, Wikström AC, Gustafsson J-Å, Yamamoto KR (1986) Genetic complementation of a glucocorticoid receptor deficiency by expression of cloned receptor cDNA. Cell 46:389-399.

MohanKumar PS, Quadri SK (1993) Systemic administration of interleukin-1 stimulates norepinephrine release in the paraventricular nucleus. Life Sci 52:1961-1967.

Morgan JI, Curran T (1991) Stimulus-transcription coupling in the nervous system: involvement of the inducible proto-oncogenes fos and jun. Annu Rev Neurosci 14:421-451.

Paxinos G, Watson C (1986) The rat brain in stereotaxic coordinates. Orlando: Academic.

Pezzone MA, Lee W-S, Hoffman GE, Rabin BS (1992) Induction of c-Fos immunoreactivity in the rat forebrain by conditioned and unconditioned aversive stimuli. Brain Res 597:41-50.

Plotsky PM, Cunningham ET Jr, Widmaier EP (1989) Catecholaminergic modulation of corticotropin-releasing factor and adrenocorticotropin secretion. Endocr Rev 10:437-458.

Riche D, Depommery J, Menetrey D (1990) Neuropeptides and catecholamines in efferent projections of the nuclei of the solitary tract. J Comp Neurol 293:399-424

Rivest S, Torres G, Rivier C (1992) Differential effects of central and peripheral injection of interleukin- 1 on brain c-fos expression and neuroendocrinc functions. Brain Res 587:13-23.

Rothwell NJ (1991) Functions and mechanisms of interleukin 1 in the brain. Trends Pharmacol Sci 12:430-436.

Saphier D, Feldman S (1989) Adrenoceptor specificity in the central regulation of adrenocortical secretion. Neuropharmacology 28:12311237.

Saphier D, Ovadia H (1990) Selective facilitation of putative corticotropin-releasing factor-secreting neurons by interleukin-1. Neurosci Lett 114:283-288.

Sapolsky R, Rivier C, Yamamoto G, Plotsky P, Vale W (1987) Interleukin-1 stimulates the secretion of hypothalamic corticotropinreleasing factor. Science 238:522-524.

Sawchenko PE, Swanson LW (1982) The organization of noradrenergic pathways from the brainstem to the paraventricular and supraoptic nuclei in the rat. Brain Res Rev 4:275-325.

Sawchenko PE, Swanson LW (1983) The organization of forebrain afferents to the paraventricular and supraoptic nuclei of the rat. J Comp Neurol 218:12 I-144.

Sawchenko PE, Swanson LW, Rivier J, Vale WW (1985) The distribution of growth-hormone-releasing factor (GRF) immunoreactivity in the central nervous system of the rat: an immunohistochemical study using antisera directed against rat hypothalamic GRF. J Comp Neurol 237:100-115.

Schmitt FO (1984) Molecular regulators of brain function: a new view. Neuroscience 13:991-1001.

Senba E, Matsunaga K, Tohyama M, Noguchi K (1993) Stress-induced c-fos expression in the rat brain: activation mechanism of sympathetic pathway. Brain Res Bull 31:329-344.

Sharp FR, Sagar SM, Hicks K, Lowenstein D, Hisanaga K (1991) c-fos mRNA, Fos, and Fos-related antigen induction by hypertonic saline and stress. J Neurosci 11:2321-2331.

Sheng M, Greenberg ME (1990) The regulation and function of $c$-fos and other immediate early genes in the central nervous system. Neuron $4: 477-485$

Shioya M, Tanaka J (1989) Inputs from the nucleus of the solitary tract to subfornical organ neurons projecting to the paraventricular nucleus in the rat. Brain Res 483:192-195.

Suda T, Tozawa F, Ushiyama T, Sumitomo T, Yamada M, Demura H (1990) Interleukin-1 stimulates corticotropin-releasing factor gene expression in rat hypothalamus. Endocrinology 126:1223-1228.

Szafarczyk A, Guillaume V, Conte-Devoix B, Alonso G, Malaval F, Pares-Herbute N, Oliver C, Assenmacher I (1988) Central catecholaminergic system stimulates secretion of $\mathrm{CRH}$ at different sites. Am J Physiol 255:E463-E468.

Tsagarakis S, Gillis G, Rees LH, Besser M, Grossman A (1989) Interleukin- 1 directly stimulates the release of corticotrophin-releasing factor from rat hypothalamus. Neuroendocrinology 49:98-101.

Uehara A, Gottschall PE, Dahl RR, Arimura A (1987) Interleukin-1 stimulates $\mathrm{ACTH}$ release by an indirect mechanism which requires endogenous corticotropin relcasing factor. Endocrinology 121:15801582.

van Dam A-M, Brouns M, Louisse S, Berkenbosch F (1992) Appearance of interleukin-1 in macrophages and in ramified microglia in the brain of endotoxin-treated rats: a pathway for the induction of nonspecific symptoms of sickness? Brain Res 588:291-296.

Wan W, Janz L, Vriend CY, Sorenson CM, Greenberg AH, Nance DM (1993) Differential induction of c-Fos immunoreactivity in hypothalamus and brain stem nuclei following central and peripheral administration of endotoxin. Brain Res Bull 32:581-587.

Whitfield HJ Jr, Brady LS, Smith MA, Mamalaki E, Fox RJ, Herkenham M (1990) Optimization of cRNA probe in situ hybridization methodology for localization of glucocorticoid receptor mRNA in rat brain: a detailed protocol. Cell Mol Neurobiol 10:145-157.

Whitnall MH (1993) Regulation of the hypothalamic corticotropinreleasing hormone neurosecretory system. Prog Neurobiol 40:573629.

Wilkinson MF, Mathieson WB, Pittman QJ (1993) Interleukin- $1 \beta$ has excitatory effects on neurons of the bed nucleus of the stria terminalis. Brain Res 625:342-346.

Wray S, Hoffman GE (1983) Organization and interrelationship of neuropeptides in the central amygdaloid nucleus of the rat. Peptides $4: 525-541$.

Zardetto-Smith AM, Gray TS (1990) Organization of peptidergic and catecholaminergic efferents from the nucleus of the solitary tract to the rat amygdala. Brain Res Bull 25:875-887. 